Jan Ptak

Katolicki Uniwersytet Lubelski Jana Pawła II

\title{
ANTYCZNA ARMIA PRZECIWKO GROŹNYM ZWIERZĘTOM W PANTEONIE SANDOMIERSKIM
}

Streszczenie. W średniowiecznym manuskrypcie, zwanym Panteonem sandomierskim, wraz z dziełem Godfryda z Viterbo znajduje się apokryficzny list Aleksandra Wielkiego do Arystotelesa. Król macedoński opisuje w nim przygody, jakie przeżywał wraz ze swoją armią w czasie wyprawy do Indii. Wśród nich dużą część zajmują walki, które musiał toczyć wraz ze swymi ludźmi z napotykanymi tam groźnymi zwierzętami, atakującymi ich w czasie tej wędrówki. Były wśród nich hipopotamy, Iwy, węże, dziki, wielkie myszy, nietoperze, skorpiony, raki, słonie, a także monstrualne stworzenia, z których jedno miało dwie głowy, inne na głowie trzy rogi, jeszcze inne - wystające z czoła ostre, zębate kości. Odpieranie ich ataków wymagało różnych sposobów i użycia broni, w którą macedońscy żołnierze byli wyposażeni. Opisy tych zmagań zostały w manuskrypcie zilustrowane barwionymi rysunkami. Król i jego podwładni zostali na nich przedstawieni zgodnie z XIV-wiecznymi realiami, natomiast wygląd zwierząt jest efektem wyobraźni rysownika. Ideowe treści tego dzieła są zbieżne z zasadami średniowiecznego rycerskiego etosu, który głosił potrzebę stawiania czoła siłom zła, symbolicznie uosabianym także przez groźne zwierzęta.

Słowa kluczowe: kultura średniowieczna, Godfryd z Viterbo, Panteon sandomierski, Aleksander Wielki, walki ze zwierzętami, etos rycerski

W'śód postaci świata antycznego cieszących się popularnością w wiekach średnich, ważne miejsce zajmował Aleksander Wielki jako niezwyciężony wódz-zdobywca, znakomity wojownik, twórca ogromnego imperium ${ }^{1}$. Jego czyny

${ }^{1}$ Aleksander Wielki na przykład jest stale obecny w popularnym w okresie średniowiecza zestawieniu tzw. Dziewięciu dzielnych, jako jeden z trzech największych bohaterów epoki pogańskiego antyku, obok Hektora i Juliusza Cezara, vide: J. Huizinga, Jesień średniowiecza, Warszawa 1992, s. 94-95. 
stały się w tej epoce tematem wielu utworów literackich i przedstawień ikonicznych. Autorów tych dzieł niejednokrotnie fascynowała okoliczność, że działaniom Aleksandra towarzyszyło przekraczanie granic znanego świata, odkrywanie nowych, tajemniczych krain i miejsc. Za szczególne osiągnięcie na tym polu uchodziła jego wyprawa do Indii podjęta w 327 r. Stała się ona tematem powstałego zapewne jeszcze we wczesnym średniowieczu, apokryficznego listu Aleksandra do Arystotelesa, który był nauczycielem przyszłego macedońskiego władcy. Utwór ten rozpowszechnił się w licznych kopiach, przy czym część z nich została zaopatrzona w ilustracje.

Jeden z egzemplarzy tego listu zachował się w Polsce w posiadaniu kapituły katedralnej w Sandomierzu (obecnie w tamtejszym Muzeum Diecezjalnym) jako część manuskryptu, zawierającego dzieło Godfryda z Viterbo, zwane z racji miejsca przechowywania Panteonem sandomierskim ${ }^{2}$. Na podstawie kolofonu powstanie kodeksu można datować na 1335 r. Manuskrypt przygotowano zapewne w Polsce, a jego znanym z imienia właścicielem był kanonik krakowskiej kapituły katedralnej o imieniu Hanko. Fragment tego kodeksu, w którym znalazł się wspomniany list Aleksandra (k. 84v-91v), został ozdobiony 28 barwionymi rysunkami, ilustrującymi tekst. W większości występuje na nich macedoński władca ze swoimi żołnierzami w scenach ukazujących doświadczane przez nich w Indiach przygody, w tym także zmagania z potwornymi bestiami. Przedstawienia te zostały poddane analizie przez Krystynę Secomską, która w ramach swych badań przepisała i przetłumaczyła fragmenty utworu odnoszące się do poszczególnych miniatur ${ }^{3}$.

Poszukując inspiracji, które wpłynęły na wygląd tych przedstawień, trzeba stwierdzić, iż zarówno król, jak i jego podwładni zostali ukazani zgodnie z realiami epoki, w której powstały. Można sądzić, że rysownik w dużym stopniu

Wśród historycznych biografii tej postaci można wymienić: P. GreEN, Aleksander Wielki, Warszawa 1978; S. Pressfield, Aleksander Wielki. Dzielność wojenna, Poznań 2004; M. Olbrycht, Aleksander Wielki i świat irański, Rzeszów 2004; K. Nawotka, Aleksander Wielki, Wrocław 2007.

${ }^{2}$ Godfryd z Viterbo (1125-1202) był niemieckim kronikarzem i poetą, autorem kilku wersji dzieła poświęconego historii świata. Jedną z nich był Panteon, obejmujący czasy do 1191 r., vide: J. WARMIŃsKi, Godfryd z Viterbo, [w:] Encyklopedia katolicka, t. 5, Lublin 1989, kol. 1227-1228.

${ }^{3}$ K. Secomska, Legenda Aleksandra Wielkiego w "Pantheonie” sandomierskim. Miniatury w kodeksie z 1335 roku, Wrocław 1977. Należy zaznaczyć, że tekst listu w sandomierskim kodeksie jest jedną z wielu różniących się między sobą wersji tego utworu, powstałych w okresie średniowiecza. 
posłużył się tu autopsją. Natomiast wygląd wspomnianych stworzeń, jak też ludzi zamieszkujących Indie, był z pewnością efektem wyobraźni jego samego bądź autora podobnych wizerunków, na których mógł się wzorować. Dzięki temu utrwalony w omawianym dziele przekaz mógł oddziaływać na czytelnika w dwójnasób - zarówno poprzez opis słowny, jak i jego graficzne ukonkretnienie.

Aleksander jest przedstawiony w tych rysunkach jak średniowieczny król, z otwartą koroną na głowie, w wierzchniej szacie sięgającej kolan, nałożonej na pancerz lub tekstylną odzież. Podobnej długości tuniki bez rękawów okrywają jego podwładnych, mających pod nimi kolczugi, osłaniające ich tułowia i kończyny razem z dłońmi i stopami. Ich głowy są chronione bądź kolczymi czepcami, bądź hełmami różnych typów. Są widoczne wśród nich kapaliny i hełmy garnczkowe, ozdobione pióropuszami lub orlimi skrzydłami. Ludzie ci są wyposażeni w trójkątne tarcze oraz broń zaczepną w postaci włóczni, mieczy, toporów i łuków. Zarówno monarcha, jak i otaczający go zbrojni w niektórych scenach dosiadają koni, w innych występują pieszo. W sumie ich wygląd jest typowy dla rycerstwa $\mathrm{z}$ pierwszych dziesięcioleci XIV w. ${ }^{4}$ Warto też zwrócić uwagę na akcenty heraldyczne i weksylologiczne w przedstawieniach owych postaci. W szczególny sposób odnosi się to do samego króla, którego herb jest widoczny zarówno na jego tarczy, jak i na towarzyszącej mu chorągwi. Otaczający go zbrojni mają też niekiedy na tarczach wymalowane motywy graficzne, które mogłyby uchodzić za ich godła.

List Aleksandra, zajmujący w sumie kilkanaście stronic manuskryptu, zawiera opisy piętnastu wydarzeń mających postać konfrontacji armii macedońskiej z groźnymi indyjskimi stworzeniami. Towarzyszy im szesnaście miniatur, gdyż jeden z takich epizodów został zilustrowany dwoma wizerunkami. Pozostałe fragmenty tego utworu wraz z resztą ilustracji odnoszą się do innych przygód, jakich doświadczył Aleksander ze swym wojskiem w Indiach.

${ }^{4} \mathrm{O}$ wyglądzie rycerstwa w tym okresie vide np. L. KAJzer, Uzbrojenie i ubiór rycerski w średniowiecznej Matopolsce w świetle źródet ikonograficznych, Wrocław 1976, s. 81-122. 


\section{Tabela 1}

\section{Zestawienie walk żołnierzy Aleksandra Wielkiego z indyjskimi zwierzętami ${ }^{5}$}

\begin{tabular}{|c|c|c|c|c|}
\hline \multirow{2}{*}{ Lp. } & \multirow{2}{*}{ Zwierzęta } & \multirow{2}{*}{ Zagrożenie } & \multicolumn{2}{|c|}{ Metody i narzędzia walki } \\
\hline & & & Tekst & Miniatura \\
\hline 1 & $\begin{array}{l}\text { hipopotamy } \\
\text { (ypotami) }\end{array}$ & $\begin{array}{l}\text { pożerały macedoń- } \\
\text { skich lekkozbrojnych } \\
\text { żołnierzy, płynących } \\
\text { łodziami po rzece }\end{array}$ & & \\
\hline 2 & $\begin{array}{l}\text { lwy, niedźwiedzie, } \\
\text { tygrysy, pantery i ry- } \\
\text { sie (leonibus ursisque, } \\
\text { tigridibus pardis ac } \\
\text { lyncibus... resisteba- } \\
\text { mus) }\end{array}$ & & $\begin{array}{l}\text { stawiali opór ataku- } \\
\text { jącym zwierzętom }\end{array}$ & konno, z włóczniami \\
\hline 3 & $\begin{array}{l}\text { skorpiony indyjskie } \\
\text { (Indie scorpiones) }\end{array}$ & $\begin{array}{l}\text { podążały z podnie- } \\
\text { sionymi żądłami } \\
\text { w ogonach do } \\
\text { jeziora, nad którym } \\
\text { żołnierze obozowali, } \\
\text { gotowe wyrządzić } \\
\text { im krzywdę }\end{array}$ & & $\begin{array}{l}\text { pieszo, z włóczniami } \\
\text { i mieczem }\end{array}$ \\
\hline 4 & $\begin{array}{l}\text { mnóstwo węży (ser- } \\
\text { pencium) - rogatych } \\
\text { i wilgotnych, roz- } \\
\text { maicie ubarwionych } \\
\text { - jedne czerwone, } \\
\text { inne czarne lub białe, } \\
\text { albo podobne do } \\
\text { złotej błyskawicy }\end{array}$ & $\begin{array}{l}\text { złe, niosące nie- } \\
\text { szczęście }\end{array}$ & $\begin{array}{l}\text { zagrodzenie dostępu } \\
\text { do obozu tarczami, } \\
\text { węże przebijane } \\
\text { długimi włócznia- } \\
\text { mi, inne niszczone } \\
\text { ogniem }\end{array}$ & $\begin{array}{l}\text { pieszo, z włóczniami } \\
\text { i tarczami }\end{array}$ \\
\hline 5 & $\begin{array}{l}\text { czubate indyjskie } \\
\text { węże (serpentes Indi- } \\
\text { ci), dwu-i trzygłowe, } \\
\text { grube jak kolumny } \\
\text { i nieco większe }\end{array}$ & $\begin{array}{l}\text { otwarte paszcze } \\
\text { z potrójnymi języka- } \\
\text { mi, oczy tryskające } \\
\text { jadem, nawet ich } \\
\text { oddech był śmier- } \\
\text { cionośny }\end{array}$ & $\begin{array}{l}\text { walka trwała nie dłu- } \\
\text { żej niż godzinę }\end{array}$ & $\begin{array}{l}\text { pieszo, z włóczniami } \\
\text { i tarczami }\end{array}$ \\
\hline
\end{tabular}

5 Fragmenty utworu dotyczące tych wydarzeń K. SECOMSKa (op. cit.) zestawiła w wersji łacińskiej i w polskim tłumaczeniu na s. 103-120. 


\begin{tabular}{|c|c|c|c|c|}
\hline \multirow{2}{*}{ Lp. } & \multirow{2}{*}{ Zwierzęta } & \multirow{2}{*}{ Zagrożenie } & \multicolumn{2}{|c|}{ Metody i narzędzia walki } \\
\hline & & & Tekst & Miniatura \\
\hline 6 & $\begin{array}{l}\text { raki (cancri) pokryte } \\
\text { krokodylową skórą }\end{array}$ & & $\begin{array}{l}\text { dzięki swym twar- } \\
\text { dym pancerzom } \\
\text { były niewrażliwe na } \\
\text { żelazo, wiele z nich } \\
\text { zniszczono ogniem }\end{array}$ & $\begin{array}{l}\text { pieszo, z włóczniami } \\
\text { i toporem }\end{array}$ \\
\hline 7 & $\begin{array}{l}\text { białe lwy (albi leones), } \\
\text { wielkie jak byki }\end{array}$ & $\begin{array}{l}\text { uderzały na żołnierzy } \\
\text { jak pioruny }\end{array}$ & $\begin{array}{l}\text { padały rażone my- } \\
\text { śliwskimi oszczepa- } \\
\text { mi (venabulis) }\end{array}$ & $\begin{array}{l}\text { pieszo, z włóczniami, } \\
\text { tarczą i mieczem }\end{array}$ \\
\hline 8 & wielkie dziki (apri) & & & $\begin{array}{l}\text { pieszo, z włóczniami } \\
\text { i tarczami }\end{array}$ \\
\hline 9 & $\begin{array}{l}\text { plamiste rysie, ty- } \\
\text { grysy oraz straszliwe } \\
\text { pantery (maculosis } \\
\text { lyncibus tigridibu- } \\
\text { sque et horribilibus } \\
\text { pantheris) }\end{array}$ & $\begin{array}{l}\text { walka, której nie da } \\
\text { się porównać z żad- } \\
\text { nym nieszczęściem }\end{array}$ & & włócznie, tarcze \\
\hline 10 & $\begin{array}{l}\text { chmara nietoperzy } \\
\text { (vespertilionum vis) } \\
\text { wielkich jak gołębie }\end{array}$ & $\begin{array}{l}\text { zębami podobnymi } \\
\text { do ludzkich atakowa- } \\
\text { ły twarze żołnierzy, } \\
\text { kaleczyły ich ciała }\end{array}$ & & $\begin{array}{l}\text { konno, z włóczniami, } \\
\text { tarczami i mieczem }\end{array}$ \\
\hline 11 & $\begin{array}{l}\text { potwór mniejszy } \\
\text { od słonia, uzbrojo- } \\
\text { ny od przodu w trzy } \\
\text { rogi (bestia minor } \\
\text { elefanto }[. . .] \text { tribus } \\
\text { armata in fronte } \\
\text { cornibus), którego } \\
\text { Indowie nazywają } \\
\text { tyrannus }\end{array}$ & $\begin{array}{l}\text { ruszył w kierunku } \\
\text { obozu }\end{array}$ & $\begin{array}{l}\text { nie mogły go po- } \\
\text { wstrzymać ogniska } \\
\text { rozpalone w ciagłej } \\
\text { linii. Król wystawił } \\
\text { oddział Macedoń- } \\
\text { czyków, z którego } \\
\text { potwór zabił } 24 \\
\text { ludzi, a } 55 \text { innych } \\
\text { stratował i pozbawił } \\
\text { zdolności do walki. } \\
\text { Został przebity } \\
\text { oszczepami (vena- } \\
\text { bulis) }\end{array}$ & $\begin{array}{l}\text { I. pieszo, z włócznia- } \\
\text { mi, tarczą i ogniem* } \\
\text { II. pieszo z włócznia- } \\
\text { mi, tarczą i mieczem }\end{array}$ \\
\hline 12 & $\begin{array}{l}\text { myszy indyjskie } \\
\text { (mures Indici) } \\
\text { podobne do lisów }\end{array}$ & $\begin{array}{l}\text { ich ugryzienie za- } \\
\text { bijało zwierzęta, ale } \\
\text { dla ludzi nie było } \\
\text { śmiertelne }\end{array}$ & & $\begin{array}{l}\text { pieszo, z włóczniami, } \\
\text { mieczem i tarczą }\end{array}$ \\
\hline
\end{tabular}


Tabela 1 (cd.)

\begin{tabular}{|c|c|c|c|c|}
\hline \multirow{2}{*}{ Lp. } & \multirow{2}{*}{ Zwierzęta } & \multirow{2}{*}{ Zagrożenie } & \multicolumn{2}{|c|}{ Metody i narzędzia walki } \\
\hline & & & Tekst & Miniatura \\
\hline 13 & $\begin{array}{l}\text { potwór (belua) } \\
\text { z grzbietem jak piła, } \\
\text { mający dwie głowy } \\
\text { - jedną podobną } \\
\text { do księżyca z piersią } \\
\text { hipopotama, i drugą } \\
\text { głowę podobną do } \\
\text { krokodyla z twardy- } \\
\text { mi zębami }\end{array}$ & $\begin{array}{l}\text { jedna z głów zabiła } \\
\text { dwóch żołnierzy } \\
\text { nagłym atakiem }\end{array}$ & $\begin{array}{l}\text { potwora zabito } \\
\text { żelaznymi młotami } \\
\text { (ferreis maleis)**, } \\
\text { nie można go było } \\
\text { przebić włóczniami }\end{array}$ & konno, z włóczniami \\
\hline 14 & $\begin{array}{l}\text { słonie (elefantorum } \\
\text { immensi greges), ma- } \\
\text { jące grzbiety czarne, } \\
\text { białe, albo czerwone, } \\
\text { niekiedy różno- } \\
\text { barwne }\end{array}$ & $\begin{array}{l}\text { podążały na ludzi } \\
\text { z wyciągniętymi } \\
\text { trąbami }\end{array}$ & $\begin{array}{l}\text { wojsko ostrzeżone } \\
\text { o ich nadejściu z lasu } \\
\text { przez ludzi dostar- } \\
\text { czających żywności } \\
\text { i opału. Król rozka- } \\
\text { zał tesalskim żołnie- } \\
\text { rzom, by zastąpili } \\
\text { im drogę, zabierając } \\
\text { ze sobą świnie, gdyż } \\
\text { słonie boją się ich } \\
\text { kwiczenia. Innym } \\
\text { z włóczniami naka- } \\
\text { zał za pomocą trąb, } \\
\text { aby piesi nie pozosta- } \\
\text { wali w obozie. Alek- } \\
\text { sander wraz z królem } \\
\text { Porusem podążał na } \\
\text { czele jazdy. Słonie } \\
\text { uciekały, zabito ich } \\
\text { około 980, podcina- } \\
\text { jąc im kolana }\end{array}$ & $\begin{array}{l}\text { pieszo, z włóczniami } \\
\text { i tarczami, świnie } \\
\text { niesione przez żoł- } \\
\text { nierzy }\end{array}$ \\
\hline 15 & $\begin{array}{l}\text { dziwne zwierzęta } \\
\text { (mirabiles feras), } \\
\text { z których głów wy- } \\
\text { stawały zębate kości } \\
\text { jak miecze*** }\end{array}$ & $\begin{array}{l}\text { zębatymi kośćmi } \\
\text { atakowały ludzi na } \\
\text { sposób byków }\end{array}$ & $\begin{array}{l}\text { bestie przebijały } \\
\text { rogami tarcze wielu } \\
\text { żołnierzy }\end{array}$ & $\begin{array}{l}\text { tarcze, włócznia, } \\
\text { jedna z tarcz przebita } \\
\text { zębatą kością }\end{array}$ \\
\hline
\end{tabular}

* Według K. Secomskiej (op. cit., s. 112 i 169) czerwone smugi biegnące pionowo pod sylwetką zwierzęcia to strugi krwi z jego ran, ale można też je interpretować jako języki ogni rozpalonych dla powstrzymania potwora, o których jest mowa w tekście.

** K. Secomska (op. cit., s. 113) przetłumaczyła ten termin jako żelazne topory, lecz wyraz maleus (poprawnie: malleus) oznacza raczej młot.

${ }^{* * *}$ K. Secomska nazywa je jednorożcami (op. cit., s. 109), jednak ta nazwa nie występuje w tekście expressis verbis.

Źródło: oprac. własne. 
Jak wynika z prezentowanego zestawienia, podwładni Aleksandra podczas kampanii w Indiach musieli nieustannie zmagać się wraz z nim z zagrożeniami, jakie niosła ze sobą dzika, nieznana im, tamtejsza natura. Wśród stworzeń, które spotykali na swej drodze, były groźne bestie, mogące zabijać ludzi. Ich sposób działania był różnorodny, ale w większości wypadków powodowały dotkliwe skutki dla atakowanych ludzi, którzy w wyniku tych starć ginęli lub odnosili ciężkie obrażenia.

Należy zw rócić uwagę na kilka istotnych cech tych zmagań. Walki z bestiami miały tam zawsze charakter obronny, a działania żołnierzy były reakcją na realne niebezpieczeństwa, jakie się pojawiały na ich drodze. W niektórych wypadkach brak jest w tekście wiadomości o jakichkolwiek działaniach polegających na odpieraniu ataku, na przykład podczas napaści hipopotamów na oddział płynący rzeką na łodziach. Nie ma też wzmianek o tym, czy walczono ze skorpionami nad brzegiem jeziora, albo z nietoperzami kąsającymi żołnierzy, jak też z indyjskimi myszami. Należy jednak zauważyć, że dla rysownika było oczywiste zbrojne odpieranie tych stworzeń, co znalazło odbicie w sporządzonych przez niego wizerunkach. W większości zestawionych w tabeli wypadków - zarówno w ich opisach, jak i tym bardziej w towarzyszących im ilustracjach - zaatakowani ludzie toczą jednak walki z zagrażającymi im zwierzętami. Używają przy tym różnych sposobów, a niekiedy też specjalnie dobranej broni.

Warto przytoczyć kilka przykładów stosowanej przez nich taktyki. Aby zatrzymać węże napastujące żołnierzy przebywających w obozie, zasłaniano dostęp do niego tarczami, a gady przebijano długimi włóczniami lub niszczono ogniem. Wzmianka o długich włóczniach być może miała sugerować, że przy użyciu takiej broni możliwe było rażenie owych groźnych stworzeń z odpowiedniego dystansu, bez narażania się na ich ukąszenia. Ale może też nawiązywać do wyposażenia piechoty macedońskiej w tzw. sarissy, czyli włócznie zaopatrzone w długie drzewca. Przy użyciu ognia rozprawiono się też z rakami, których twarde pancerze były odporne na ciosy zadawane żelazną bronią. Z kolei w walce z dwugłowym potworem włócznie okazały się nieskuteczne, zabito go dopiero żelaznymi młotami. Innej groźnej bestii, mającej na głowie trzy rogi, nie udało się odeprzeć przy użyciu ognisk ułożonych w ciągłą linię, uporano się z nią natomiast dzięki myśliwskim oszczepom. Ta sama broń okazała się skuteczna w rozprawieniu się z białymi lwami. W opisie starcia z bestiami mającymi na głowach kościste szpikulce jest mowa jedynie o zasłanianiu się od ich ciosów tarczami. Nie dawały one jednak skutecznej osłony, gdyż były przebijane tymi rogami. 
Najbardziej obszerny i szczegółowy opis dotyczy walki z olbrzymim stadem słoni, które wynurzyły się z lasu nad rzeką Buemar. Niezwykłym sposobem na ich odparcie okazało się użycie kwiczących świń, które swym głosem odstraszały intruzów. Ale walka z nimi wymagała zaangażowania dużej liczby żołnierzy zarówno konnych, jak i pieszych. Podobnie jak w regularnej bitwie, wojsku wydawano polecenia przy użyciu trąb. Sam Aleksander, wraz z towarzyszącym mu w tej wyprawie indyjskim królem Porusem, stanął na czele konnicy. Starcie zakończyło się zwycięstwem jego armii, groźne stworzenia zostały zmuszone do ucieczki, a niemal tysiąc z nich padło z rąk jeźdźców. Powalano je, podcinając im kolana. Co ciekawe, Porus przedstawił Aleksandrowi możliwość schwytania tych zwierząt i wykorzystania ich do celów wojennych, do czego ostatecznie nie doszło.

Rysunki ilustrujące tekst listu Aleksandra ukazują te wydarzenia w dość specyficzny sposób. Zwierzęta atakujące wojska macedońskie mają zazwyczaj fantazyjny wygląd, nawet jeżeli reprezentują gatunki realnie istniejące, takie jak słonie, lwy, rysie, dziki, węże czy nietoperze. Specyficznym wytworem wyobraźni twórczej są natomiast stworzenia wynaturzone, jak choćby potwór dwugłowy, czy też inny - mający trzy rogi, podobnie też dwu-i trzygłowe węże oraz zwierzęta z pojedynczymi naroślami kostnymi w kształcie mieczy na głowach. Dodatkowo w scenie walki z drapieżnikami (w tekście wymienione lwy, niedźwiedzie, tygrysy, pantery i rysie) obok drapieżnego zwierzęcia pokrytego cętkami rysownik umieścił dwa smoki. Ich przeciwnikami są żołnierze Aleksandra, walczący najczęściej pieszo, a dosiadający koni tylko w kilku scenach: $\mathrm{w}$ walce ze wspomnianymi wyżej drapieżnikami, ponadto też z nietoperzami i dwugłowym potworem. We wszystkich tych zmaganiach przedstawieni na rysunkach zbrojni posługują się głównie włóczniami, niekiedy i mieczami, w jednym wypadku (w walce z rakami) w użyciu jest również topór. Są wyposażeni także w tarcze, służące do osłaniania się przed wrogim atakiem. W jednym wypadku - w scenie walki z potworami mającymi na głowach pojedyncze rogi - rysownik ukazał tarczę przebijaną takim rogiem, trzymaną przez żołnierza, który pada na ziemię. Jest to więc nawiązanie do wspomnianego wyżej fragmentu tekstu, w którym była mowa o nieskuteczności tarcz w odpieraniu ataków tych zwierząt.

W charakterystyczny sposób Aleksander przedstawił w tym utworze swój udział w opisywanych starciach. Choć odgrywał w armii rolę najbardziej ekspo- 
nowaną, jako jej wódz, a zarazem jeden z najsłynniejszych w dziejach autorytetów w dziedzinie strategii i taktyki, jedynie w opisie paru omawianych tu epizodów wspomina o swej rozkazodawczej aktywności. Po raz pierwszy czyni to relacjonując oblężenie indyjskiego grodu przez jego armię, gdy wysłał (misi) dwustu lekkozbrojnych Macedończyków, by łodziami zbliżyli się do tego obiektu. Jak już wspomniano, akcja ta nie powiodła się, gdyż żołnierze ci zostali na rzece zaatakowani i pożarci przez hipopotamy. Po raz drugi mówi na swój temat we fragmencie odnoszącym się do walki ze słoniami. Na wieść o ich zbliżaniu się Aleksander wydał rozkaz (imperavi) tesalskim żołnierzom, aby w tym celu zabrali ze sobą świnie. Następnie wspomina o swoim poleceniu skierowanym do pieszych (precepi), aby nie pozostawali w obozie ${ }^{6}$. Należy też zauważyć, że przy tej okazji macedoński monarcha wzmiankuje o doniosłej roli towarzyszącego mu indyjskiego króla Porusa. Przedstawia go jako specjalistę od militarnego wykorzystania słoni. Wynikało to zapewne ze znanego z historii faktu, że Porus, będąc wcześniej przeciwnikiem Aleksandra, stoczył z nim w 326 r. p.n.e. przegraną bitwę nad rzeką Hydaspes w Pendżabie, używając w niej na dużą skalę słoni bojowych.

Natomiast pisząc o wszystkich innych rozpatrywanych tu wypadkach, Aleksander używa pierwszej osoby liczby mnogiej. Relacjonuje zachowania atakowanych żołnierzy, podając się niejako za jednego z nich. Walkę z drapieżnikami określił więc wyrażeniem „stawialiśmy opór” (resistebamus), przy odpieraniu węży użył zwrotu „w swoich rękach mieliśmy długie włócznie” (in manibus nostris longas habebamus hastas), o pokonanych lwach napisał „padają rażone naszymi oszczepami” (excepti nostris venabulis ruunt), o zabiciu zaś dwugłowego potwora: „z trudem zatłukliśmy tę bestię żelaznymi młotami” (Quam beluam ferreis maleis vix comminuimus). Podobna forma wypowiedzi została zastosowana i w pozostałych opisach.

Można w tym widzieć swoistą powściągliwość w eksponowaniu własnych sukcesów, jaką autor utworu chciał przypisać Aleksandrowi, zamierzając, być może, uchronić go przed zarzutem pychy i chęci wynoszenia się. Ale jest to jednocześnie istotny przejaw mentalności wojskowej, polegający na docenianiu działania zbiorowego, wynikającego z potrzeby skoordynowania wysiłków wielu

${ }^{6}$ Ten fragment tekstu w sandomierskim kodeksie wydaje się skażony przez kopistę. We „wzorcowej” wersji, pochodzącej z IX w. (vide: K. SecomskA, op. cit., s. 114) jest mowa o rozkazie Aleksandra (iussi) do pieszych, by w obozie pozostali. 


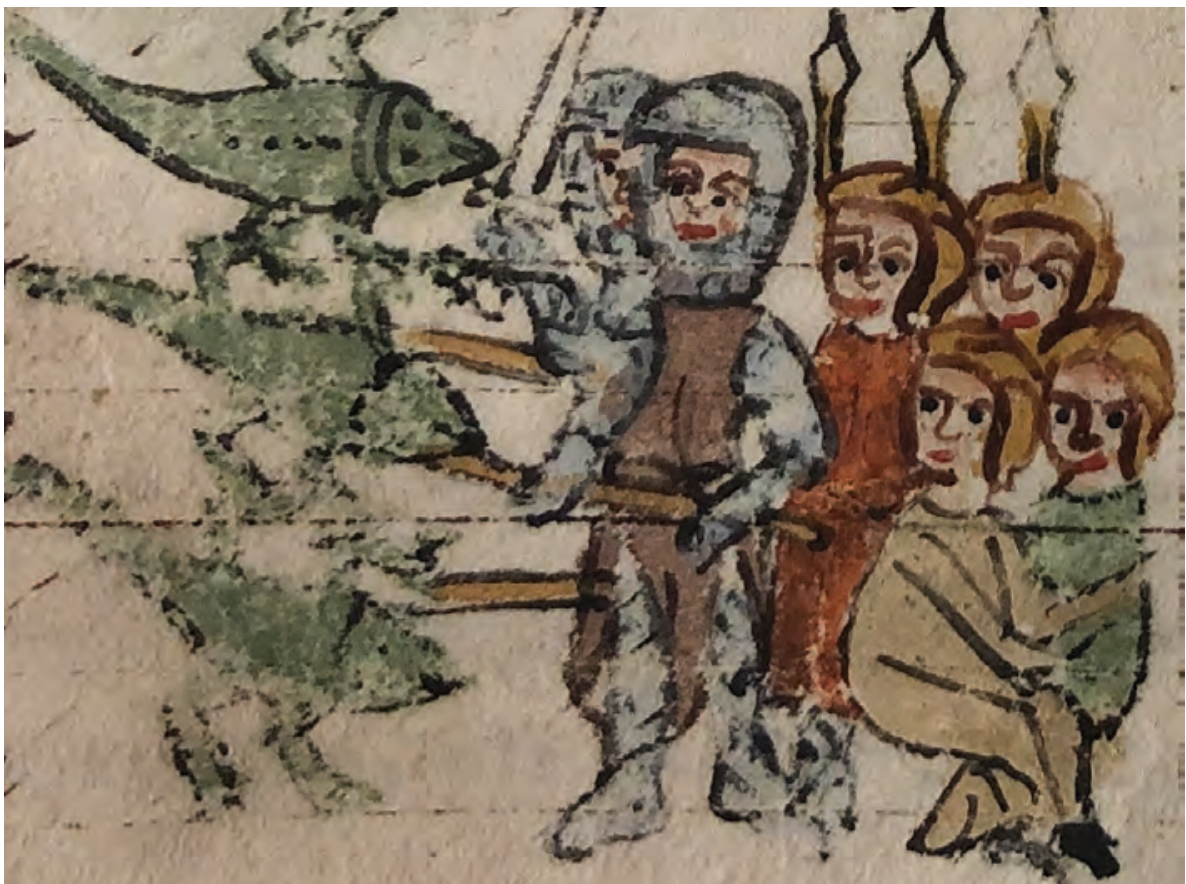

Ryc. 1. Panteon sandomierski, walka z indyjskimi skorpionami (zob. tab. I, poz. 3) - fot. ks. AndRzeJ RusAK

ludzi dla osiągnięcia militarnego sukcesu. Co ciekawe, w epoce średniowiecza, w której ten rzekomy list cieszył się popularnością, taki aspekt etosu ludzi wojny nie był zbyt powszechnie akceptowany. W ramach dominującej w tamtych czasach wojskowości rycerskiej bitwy polegały w gruncie rzeczy na staczaniu pojedynków przez ustawionych w szykach po obu stronach rycerzy ${ }^{7}$. Pod względem prestiżowym bardziej liczyły się wówczas ich indywidualne wyczyny niż walka zespołowa, w której postacie pojedynczych uczestników stawały się anonimowe i trudno dostrzegalne. Być może więc w obrazie takiego modelu zbrojnego mierzenia się z przeciwnikiem, jaki jest zawarty w utworze, zachowały się echa starożytnych tradycji wojskowych. Nie musiały się one wiązać konkretnie z armią Aleksandra, ale choćby z siłami zbrojnymi imperium rzymskiego, które przez wieki nie miały sobie równych pod względem organizacji i umiejętności skutecznego działania.

7 Ph. Contamine, Wojna w średniowieczu, Warszawa 1999, s. 238. 


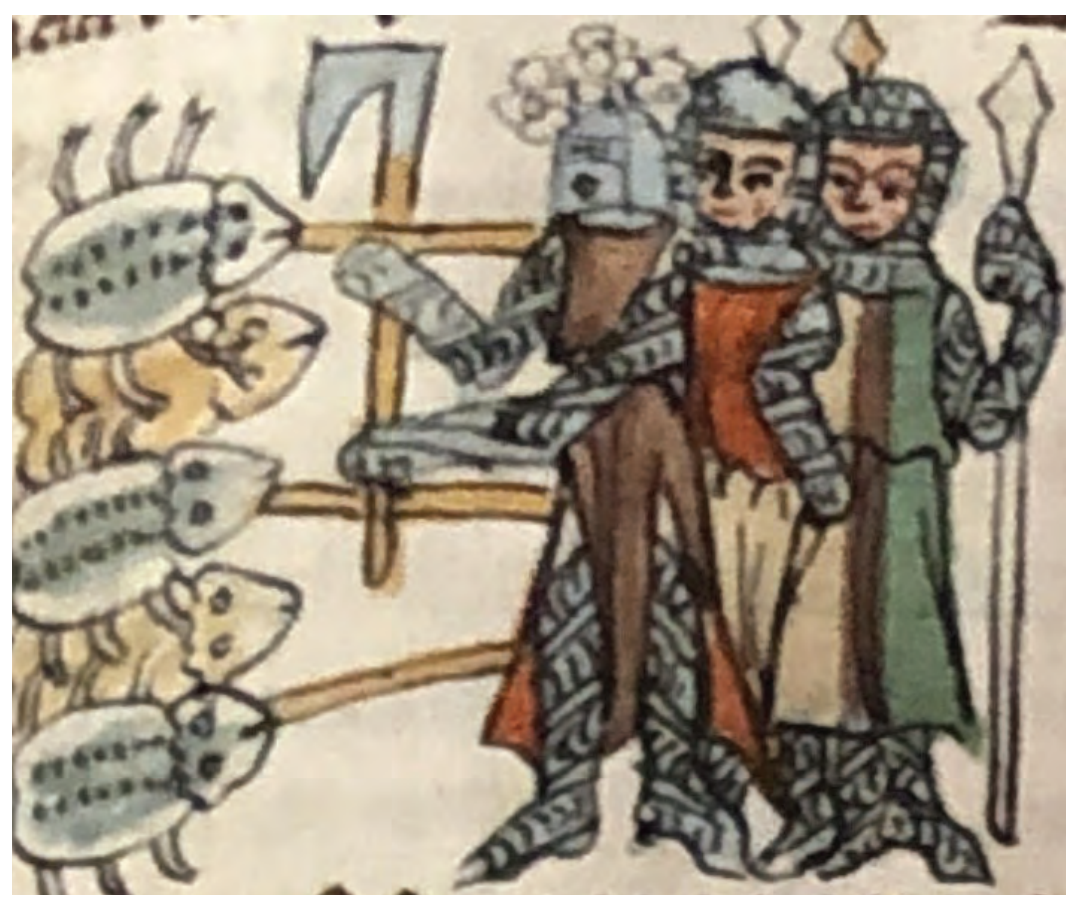

Ryc. 2. Panteon sandomierski, walka z rakami (zob. tab. l, poz. 6) - fot. ks. AndRzeJ Rusak

Można zadać pytanie, czy list Aleksandra mógł w Polsce średniowiecznej być przyjmowany przez potencjalnych odbiorców tylko jako interesująca opowieść o zamierzchłych czasach i egzotycznych krainach, czy także jako dzieło zawierające aktualne przesłanie, na przykład idee bliskie ówczesnemu etosowi rycerskiemu. Jak się wydaje, rozpatrując to zagadnienie warto byłoby zwrócić uwagę na kilka obecnych w nim aspektów działań macedońskiego króla i jego podwładnych.

Jednym z nich jest odkrywczy, eksploratorski wymiar ich wyprawy, polegający na wkroczeniu do nieznanych im krajów, pełnych tajemnic i niespodzianek. W polskich warunkach ten efekt wojen zazwyczaj nie występował, gdyż zbrojne wyprawy były najczęściej kierowane na ziemie najbliższych sąsiadów, niewiele różniące się wyglądem i charakterem od własnych. Jednak pewne zafascynowanie tajemniczością najeżdżanych terytoriów można zauważyć na przykład w utrwalonych w kronice Galla Anonima opisach polskich działań skierowanych na Pomorze w czasach Bolesława Krzywoustego. Jego wojska po uciążliwym przebyciu pasa trudno dostępnych puszcz, oddzielających ziemie 


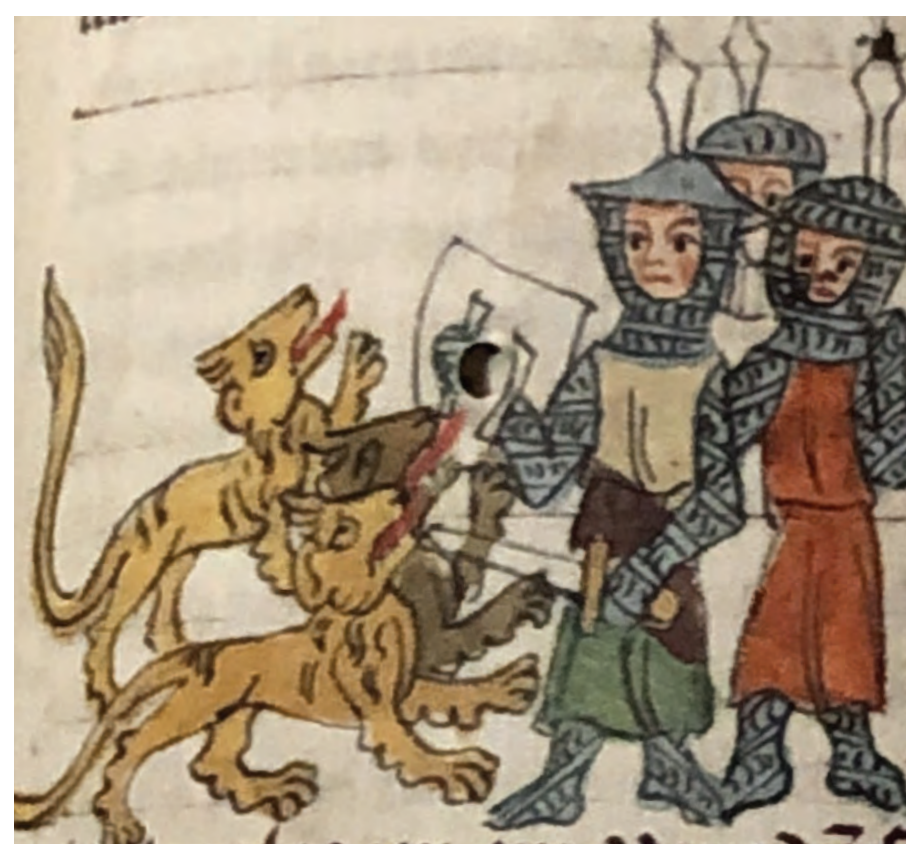

Ryc. 3. Panteon sandomierski, walka z białymi Iwami (zob. tab. I, poz. 7) - fot. ks. AndRzeJ Rusak

polskie od pomorskich i sforsowaniu pogranicznych grodów, docierały do dużych ośrodków, bogatych dzięki nadmorskiemu położeniu. Wówczas też następowało zetkniecie Polaków z nieznanym im dotąd żywiołem, jakim było morze. Odzwierciedleniem przekonania o doniosłości tych osiągnięć stała się pieśń, którą kronikarz włożył w usta uczestników wyprawy na Kołobrzeg w 1103 r., gdy osiągnęli brzeg Bałtyku.

Naszym ojcom wystarczały ryby słone i cuchnące,

My po świeże przychodzimy, w oceanie pluskające

Ojcom naszym wystarczało, jeśli grodów dobywali,

A nas burza nie odstrasza ni szum groźny morskiej fali.

Nasi ojce na jelenie urządzali polowanie

A my skarby i potwory łowim, skryte w oceanie! ${ }^{8}$

${ }^{8}$ W oryginale: monstra maris, vide: Anonima tzw. Galla Kronika czyli dzieje ksiażat i wtadców polskich, wyd. K. Maleczyński, [w:] Pomniki Dziejowe Polski, seria 2, t. 2, Kraków 1952, s. 97, polski przekład: ANONim Tzw. GaLL, Kronika polska, Wrocław 1989, s. 97. 


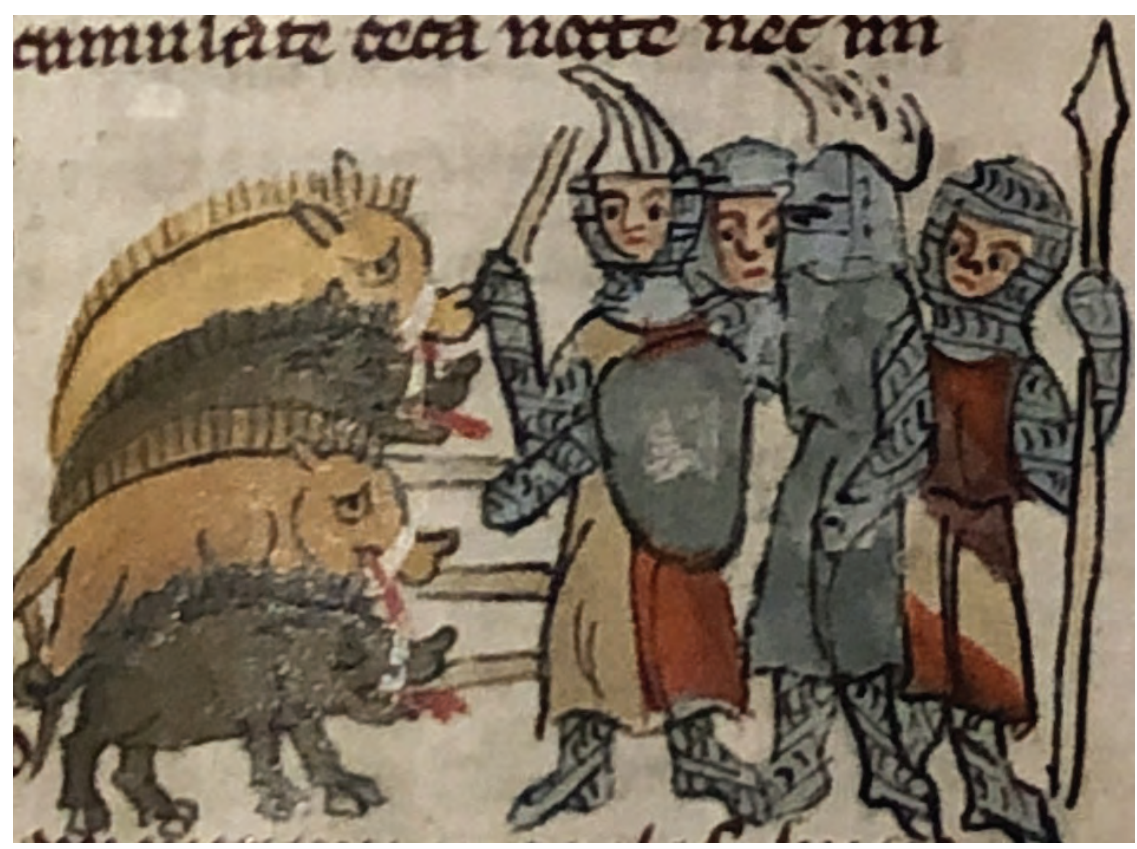

Ryc. 4. Panteon sandomierski, walka z wielkimi dzikami (zob. tab. I, poz. 8) - fot. ks. ANDRZEJ RUSAK

W tych słowach można dostrzec dumę zdobywców i ich przeświadczenie o tajemniczej i groźnej niezwykłości miejsc, do których dotarli. Zarazem mowa jest tam nie tylko o perspektywie uzyskania morskich bogactw, lecz również zetknięcia się i zmierzenia z nieznanymi im dotąd potworami. Te sformułowania są co prawda bardzo ogólnikowe i tylko potencjalnie odnoszą się do odkrywania nowych światów i szukania w nich zdobyczy, ale z pewnością odzwierciedlają właściwą dla ideologii rycerskiej skłonność do podejmowania wyzwań, mierzenia się z niebezpieczeństwami, szukania sławy i sukcesów. To w jakiś sposób może upodabniać osiągnięcia żołnierzy Aleksandra i wojów Krzywoustego, choć te drugie miały nieporównywalnie mniejszą skalę.

Inny element rycerskiego etosu, na który należy zwrócić uwagę, to gotowość do konfrontacji z siłami zła, których symbolem mogły być także groźne zwierzęta ${ }^{9}$. Motyw ten był bardzo rozpowszechniony w średniowiecznej kulturze, mając rozmaite korzenie - zarówno w Biblii, jak i w pogańskich mitologiach,

9 Vide: S. KobIelus, Bestiarium chrześcijańskie. Zwierzęta w symbolice i interpretacji. Starożytność i średniowiecze, Warszawa 2002, s. 109 (gryf), 184 (lew), 296 (smok). 


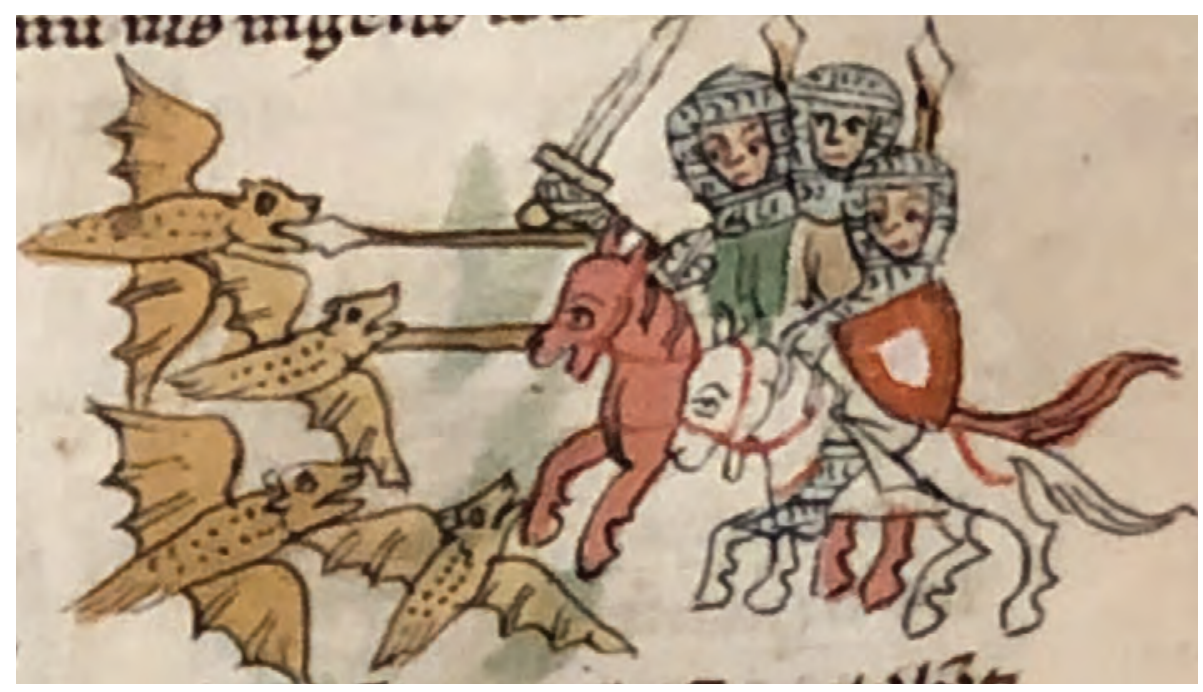

Ryc. 5. Panteon sandomierski, atak nietoperzy (zob. tab. I, poz. 10) - fot. ks. ANDRZEJ RUSAK

w eposach wielu ludów i w chrześcijańskiej hagiografii. W analizowanym tu utworze król Aleksander, podejmując takie akcje, może być zaliczony do grona bohaterów dających odpór złym mocom, zwłaszcza że większość zwierząt, z którymi walczył na czele armii, to androphagi - istoty niosące ludziom zagładę $^{10}$.

Charakterystyczną formą obecności motywu zmagań z nimi są w polskiej kulturze wizerunki na pieczęciach kilku dzielnicowych książąt w XIII w., którzy zostali tam przedstawieni jako rycerze toczący walki z lwami, smokami lub gryfami. Są to pieczęcie Kazimierza Konradowica (dwie wersje) i jego syna Siemomysła inowrocławskiego zmagających się z lwami, a także kolejne dwie z tym motywem, należące do brata Kazimierza, księcia czerskiego i mazowieckiego Siemowita I. Inne ukazywały Leszka Czarnego jako księcia sieradzkiego w starciu z gryfem i Bolesława Pobożnego z Wielkopolski walczącego ze skrzydlatym smokiem. Do tej grupy można jeszcze dołączyć pieczęć księcia wielkopolskiego i krakowskiego Przemysła II z lat 1290-1295, wyobrażonego na niej z pokonanym smokiem pod nogami ${ }^{11}$. W sumie okres występowania tych wizerunków

10 K. Secomska, op. cit., s. 197.

11 S.K. Kuczyński, Pieczęcie książąt mazowieckich, Wrocław 1978, s. 139-145; Z. Piech, Ikonografia pieczęci Piastów, Kraków 1993, s. 209-217. 


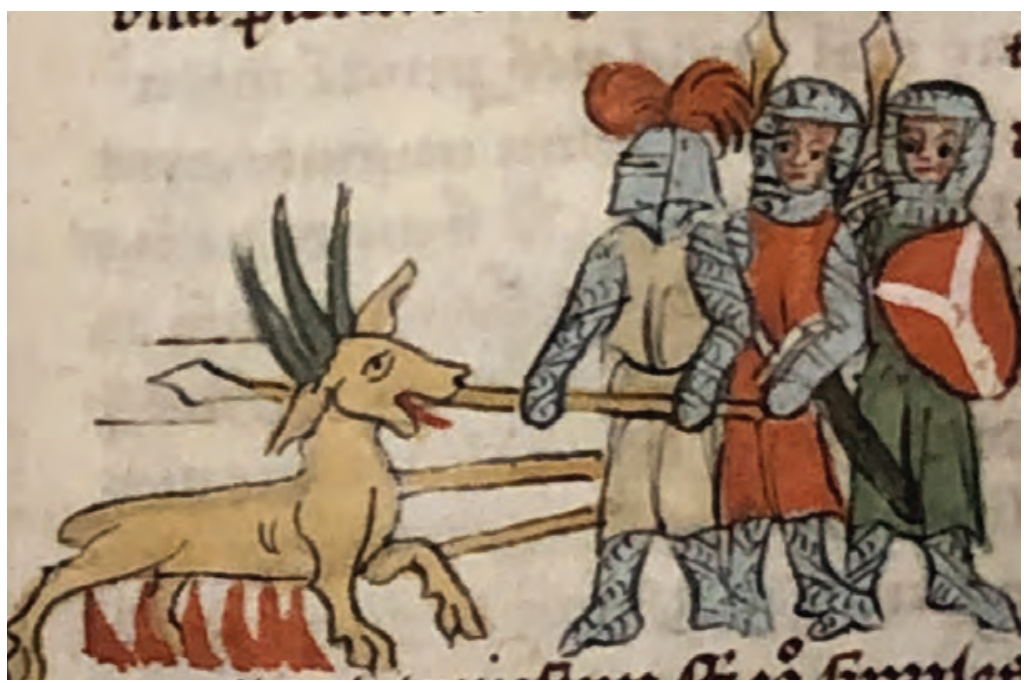

Ryc. 6. Panteon sandomierski, atak trójrogiej bestii (zob. tab. I, poz. 11) - fot. ks. ANDRZEJ RusaK

na zabytkach sfragistycznych zamyka się w drugiej połowie XIII w. Podobne przedstawienia można znaleźć na piastowskich monetach, i to już w czasach Bolesława Krzywoustego, który w 1103 r. wyemitował denary z wizerunkiem rycerza walczącego ze smokiem. Ten sam motyw znalazł się na rewersie denara Władysława Wygnańca z lat 1140-1144. Później sceny zmagań ludzi z groźnymi bestiami pojawiły się na brakteatach Mieszka Starego z lat 1182-1202 (ze smokiem) i Bolesława Wstydliwego po 1228 (z turem) ${ }^{12}$. W większości wypadków postacie ludzkie przedstawione w tych scenach oznaczają samych książąt, jako właścicieli pieczęci lub emitentów monet. Są oni wyposażeni w broń typową dla rycerzy, chronieni przez zbroje, tarcze i hełmy. Z kolei bestie toczące z nimi walkę mają prawie zawsze proweniencję fantastyczną (smoki, gryfy) lub egzotyczną (lwy). Jak już wspomniano, interpretatorzy tych wizerunków dostrzegają w nich symboliczne przedstawienia złych mocy, niosących ludziom zgubę fizyczną i duchową ${ }^{13}$.

12 J.A. SzWAGrzy , Pieniadz na ziemiach polskich X-XX w., Wrocław 1990, s. 31-35; W. GARBACZEWSKI, Ikonografia monet piastowskich 1173 - ok. 1280, Warszawa 2007, s. 208-213.

13 Vide: P. STróżyк, O możliwych inspiracjach ikonografii niektórych pieczęci Piastów w XIII wieku, [w:] Dawne pieczęcie. Typologia - metody badań - interpretacje, red. Z. РIECH, Warszawa 2015, s. 255266, tam obszerne omówienie pieczęci ze scenami walki z potworami oraz wcześniejsza literatura. 


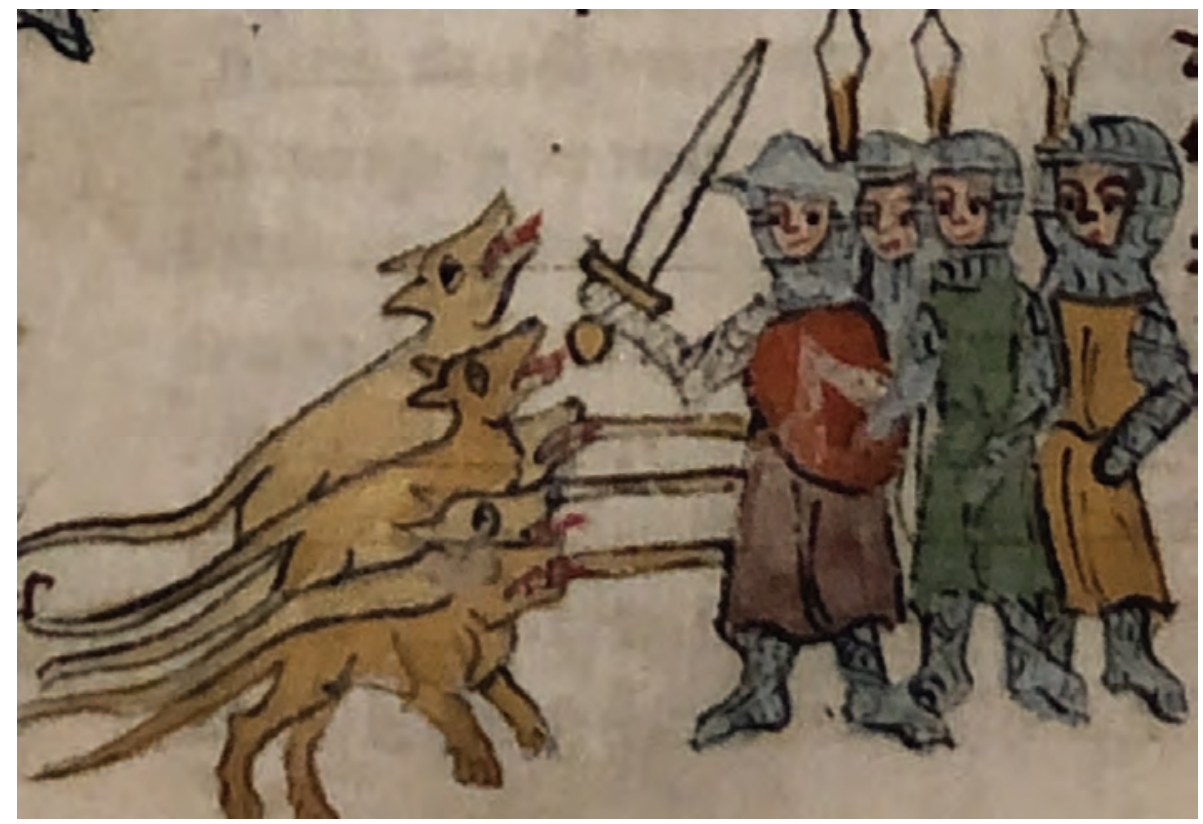

Ryc. 7. Panteon sandomierski, atak indyjskich myszy

(zob. tab. l, poz. 12) - fot. ks. ANDRZEJ RUSAK

Można dopatrywać się pewnych analogii pomiędzy scenami obecnymi na wspomnianych wyżej monetach i pieczęciach a opisanymi w rzekomym liście Aleksandra Macedońskiego. Co prawda występuje między nimi pewna zasadnicza różnica, gdyż w Indiach odbywały się walki zbiorowe, tu zaś pojedynki, w których książęta stawiają czoła bestiom indywidualnie. Z drugiej jednak strony ukazanie każdego z nich jako rycerza mogło też wywoływać skojarzenie z całym stanem rycerskim, w obrębie którego książę był postrzegany jako primus inter pares. Jego zbrojna konfrontacja z potworem mogła więc symbolizować idee bliskie wszystkim członkom tej zbiorowości. W tej postaci walka ze złem stawała się udziałem całego rycerstwa, podobnie jak cała armia Aleksandra stawiała w Indiach opór groźnym bestiom.

Zastanawiając się nad możliwościami praktycznego wykorzystania listu Aleksandra umieszczonego w Panteonie sandomierskim w epoce, w której ten manuskrypt powstał, należy przyjąć, że zawierał on treści atrakcyjne nie tylko dla bezpośrednich czytelników tego dzieła, którymi wówczas byli głównie duchowni. Ich potencjalnymi odbiorcami mogli być także ci, którzy poznawali 
ten utwór poprzez słuchanie fragmentów tłumaczonych im z łaciny, a także oglądanie zamieszczonych w księdze rysunków. Dla tych celów zostały one zapewne wykonane i to niezbyt starannie, być może w pośpiechu, w dodatku przez słabego artystę. Ich główną funkcją nie było więc zapewne dekorowanie kart manuskryptu, jak w przypadku większości dzieł ówczesnego malarstwa książkowego, lecz dopełnienie informacji zawartych w tekście. Można sądzić, że tak skonstruowany przekaz trafiał także do ludzi z kręgów rycerstwa, będącego w tamtym okresie grupą in gremio jeszcze niepiśmienną, ale kształtującą swój etos na podstawie ówczesnej kultury elitarnej, rozwijanej w środowiskach kościelnych i dworskich.

\section{BIBLIOGRAFIA}

\section{Źródła archiwalne}

Epistola Alexandri Magni ad Aristotelem magistrum suum de situ et mirabilis Indiae, [w:] Pantheon, Archiwum Diecezjalne w Sandomierzu, rkps sygn. 114, k. 84v-91v.

\section{Źródła drukowane}

Anonim tzw. Gall, Kronika polska, wyd. M. Plezia, Wrocław 1989.

Anonima tzw. Galla Kronika czyli dzieje książą i wtadców polskich, wyd. K. Maleczyński, [w:] Pomniki Dziejowe Polski, seria 2, t. 2, Kraków 1952.

\section{Opracowania}

Contamine Ph., Wojna wśredniowieczu, Warszawa 1999.

Garbaczewski W., Ikonografia monet piastowskich 1173 - ok. 1280, Warszawa 2007.

Green P., Aleksander Wielki, Warszawa 1978.

Huizinga J., Jesień średniowiecza, Warszawa 1992.

Kajzer L., Uzbrojenie i ubiór rycerski w średniowiecznej Matopolsce w świetle źródet ikonograficznych, Wrocław 1976.

Kobielus S., Bestiarium chrześcijańskie. Zwierzęta w symbolice i interpretacji. Starożytność iśredniowiecze, Warszawa 2002.

Kuczyński S.K., Pieczęcie książą mazowieckich, Wrocław 1978. 
Nawotka K., Aleksander Wielki, Wrocław 2007.

Olbrycht M., Aleksander Wielki i świat irański, Rzeszów 2004.

Piech Z., Ikonografia pieczęci Piastów, Kraków 1993.

Pressfield S., Aleksander Wielki. Dzielność wojenna, Poznań 2004.

Secomska K., Legenda Aleksandra Wielkiego w „Pantheonie” sandomierskim. Miniatury w kodeksie z 1335 roku, Wrocław 1977.

Stróżyk P., O możliwych inspiracjach ikonografii niektórych pieczęci Piastów w XIII wieku, [w:] Dawne pieczęcie. Typologia - metody badań - interpretacje, red. Z. Piech, Warszawa 2015, s. 255-266.

Szwagrzyk J.A., Pieniadz na ziemiach polskich X-XXw., Wrocław 1990.

Jan Ptak

\section{THE ANCIENT ARMY AGAINST DANGEROUS ANIMALS IN THE PANTHEON OF SANDOMIERZ}

Summary. In the medieval manuscript, called the Pantheon of Sandomierz, together with Godfred's work from Viterbo, there is an apocryphal letter from Alexander the Great to Aristotle. In it, the Macedonian king describes the adventures he experienced with his army during his expedition to India. A large part of them are the battles he had to fight together with his people with the dangerous animals he met there, attacking them during this journey. These included hippos, lions, snakes, boars, big mice, bats, scorpions, crayfish, elephants, and monstrous creatures, one of which had two heads, the other had three horns on its head, and the other had sharp, toothed bones protruding from its forehead. To resist their attacks, they required different ways and the use of weapons that Macedonian soldiers were equipped with. The descriptions of these struggles are illustrated by colored drawings in the manuscript. The king and his subordinates were depicted on them in accordance with the fourteenth century realities, while the appearance of the animals is an effect of the draftsman's imagination. The ideal content of this work is consistent with the principles of the medieval knightly ethos, which preached the need to face the forces of evil, symbolically embodied also by dangerous animals.

Keywords: medieval culture, Godfryd of Viterbo, Sandomierz Pantheon, Alexander the Great, fighting animals, knightly ethos 